\title{
Relevance of Electrical Resistivity Geophysical Method in Engineering Site Characterization in A Basement Complex Terrain
}

\author{
Adiat KAN* \\ Federal University of Technology, Akure, Nigeria
}

*Corresponding author: Adiat KAN, Federal University of Technology, Akure, Nigeria.

Received Date: February 05, 2019

Published Date: March 26, 2019

\begin{abstract}
In this study, relevance of electrical resistivity geophysical technique in engineering site characterization had been demonstrated. The aim of the study was to establish the capability of the technique to unravel subsurface conditions through quantitative assessment/evaluation of subsurface geoelectric parameters. In order to achieve the objectives of the study, twenty (20) VES were acquired using R-50 Resistivity meter. The results obtained from both the qualitative and quantitative interpretations of the VES data were utilized in preparing geoelectric sections and some important layers parameters maps. The dominant curve types obtained suggest that the study area is largely characterized by the presence of highly weathered/fractured basement with evident of saturation. Three geologic layers were generally delineated, and these were top soil, weathered/fractured basement and the basement. The top soil was observed to be of thin thickness indicating that the foot of the foundation might inevitably be extended to the layer underlain the top soil. Series of linear features such as basement depressions and ridges, fracture, geologic contacts etc. capable of aggravating foundation failure were observed in some parts of the area. The study has consequently established the efficacy of electrical resistivity as a geophysical tool that can complement conventional geotechnical studies in engineering site characterization.
\end{abstract}

Keywords: Foundation failure; Geotechnical; Subsurface competence; Site characterization

\section{Introduction}

Conducting a geotechnical characterization of a site involves: completing document reviews, soil sampling, in-situ testing, and/or laboratory analysis of samples from the area under characterization (Day, 2006). Materials of interest to geotechnical engineer in site characterization are the soil and rock formations. These materials, apart from not being manufactured, do not possess a consistent and homogeneous set of properties. In addition to these, location and geologic histories also play significant role in the uniqueness and peculiarity of these materials. Consequently, it is important to properly and adequately characterize a site before design and construction are initiated. Site characterization can be broadly described as the defining of existing soil properties at a given site [1]. This is because understanding the properties of the subsurface allows the geotechnical engineer to predict soil behavior under a myriad of scenarios. Furthermore, it will also assist in making informed recommendations regarding appropriate foundation types, means for mitigating or preparing existing soil conditions for construction, and forecasting potential issues during construction.

Although various advancements in the field of in-situ testing have improved the quality of collected soils data; however, known conditions are still point specific and thus limited to a confined area; consequently, data must be extrapolated amongst an entire soil mass for design purposes. This extrapolation often leads to making some assumptions about earth conditions. Such assumptions can at times lead to structural failure which can culminate to loosing of lives and properties. This is because undetected, but possibly existing natural and/or man-made anomalies can nullify constant earth assumptions often used during the analysis and evaluation of geotechnical data. Encountering anomalous conditions during site development and construction can lead to truncation, interruptions or complete abandonment of the entire project schedule. It can also lead to additional labor and material costs, and capable of posing 
potentially safety risks. It is for these reasons that improved and holistic site characterization is required before the commencement of any engineering structures. Geotechnical engineers need sound means to bridge point data acquired during conventional geotechnical field operations, in a timely and cost efficient manner [2].

Innovative near-surface geophysical testing methods have both been improved and developed by geophysicists and these have tremendously increased the ease and ability to visualize subsurface conditions and anomalies. Advancements in data acquisition and interpretation have improved efficiency thereby making the use of geophysical surveying logistically feasible for several different project applications [3].

Geophysics is the application of physics principles to the study of the Earth. The Earth is comprised of materials that have different physical properties. Geophysical instruments are designed to map spatial variations in the physical properties of the Earth. Geophysicists interpret these measured variations and use them to generate geologic models of varying sophistication. If the subsurface target of interest can be differentiated from the encompassing strata on the basis of contrasting physical properties, the output geologic model can be of great utility to a geotechnical engineer.

Geotechnical/engineering geophysics is the application of geophysics to geotechnical engineering problems; such investigations normally extend to a total depth of less than several hundred feet but can be extended to thousands of feet in some instances [4].

An engineering geophysical survey is often the most costeffective and rapid means of obtaining subsurface information, especially over large study areas [5]. Geotechnical/ engineering geophysics can be used to select borehole locations and can provide reliable information about the nature and variability of the subsurface between existing boreholes. Isolated geologic structures/features such as a limestone pinnacle, fracture or fault etc. might not be detected by a routine drilling program. An effective geophysical survey could, however, detect or delineate the presence of such features and subsequently map both the depth and aerial extent of the same. Other advantages of geotechnical geophysics are related to site accessibility, portability, noninvasiveness, and operator safety.

In the recent past, geophysical methods have been implemented in solving a wide of problems in civil and environmental engineering. Such applications include building foundations/ dam axis investigations [6-8], geological features delineation and determination of the physical parameters of the rock formations. "The sources of hazards in civil engineering disciplines result essentially from undetected near-surface structures, such as cavities and/or inhomogeneities in the foundation geomaterials [9]. Application of geophysical method(s) can offer useful information in respect of the early detection of potentially dangerous subsurface features [9].

It must however be emphasized that geotechnical/engineering geophysics is not a substitute for boring and direct physical testing.
Rather, it complements a well-planned, cost-effective drilling and testing program, and provides a volumetric image of the subsurface rather than a point measurement. In fact, geophysicists refer to borehole information and field geologic maps as "ground truth," and rely on ground truth to constrain and verify all geophysical interpretations. In this study, attempt is made to establish the efficacy of the electrical resistivity geophysical prospecting technique as a complimentary tool to geotechnical studies in engineering site characterization. In addition to this, the study also intends to achieve the following objectives:

- $\quad$ To determine subsurface stratigraphic sequence and its geoelectric parameters underlain the study area

- $\quad$ To identify the presence of geologic structures such as fractures, faults, geologic contacts/joints and other weak zones capable of undermining integrity of engineering structures in the study location.

- To assess/evaluate the geoelectric parameters distribution of each of the subsurface layers and their attendant implication(s) on foundation integrity

- $\quad$ To establish the relevance of geophysical investigation as a complimentary tool to geotechnical studies in engineering site characterization

\section{Description of the Study Area}

The study location, a privately owned housing estate, is in Akure, Capital of Ondo State, south western Nigeria. It is located between the coordinates: Easting $743180 \mathrm{~m}$ to $743380 \mathrm{~m}$ and Northing $805200 \mathrm{~m}$ to $805530 \mathrm{~m}$ (Figure 1). The area has a low lying topography. The study area is geographically located within the sub-equatorial climate belt of tropical rain-forest vegetation with evergreen and broad-leaved trees luxuriant growth layer arrangement. The Akure area is characterized by uniformly high temperature and heavy, well distributed rainfall throughout the year but onset is during the month of march and ceastion (sharp decrease in amount) is during the month of November. June through September are the critical months. During June through September, rainfall is critical, and the amount is usually high, thus leading to high probability of soil erosion and flooding. July and September are the first and second peak months respectively. These two months are very significant because of sporadic, heavy down pours. At times, rainfall in excess of $40 \mathrm{~mm}$ is recorded on a single day while the average annual rainfall is $1333.2 \mathrm{~mm}$. the annual mean temperature is $330 \mathrm{C}$ while the mean minimum is $180 \mathrm{C}$. Evaporation is usually low from June through September, ranging from $3.3 \mathrm{~mm}$ to $4.0 \mathrm{~mm}$ per day. Sunshine duration is short (2.7 to 2.9 hours per day) during the month or July to September, while the relative humidity ranges from 5.0 to $90 \%$ depending on the season [10]. Vegetation in the study area is of rainforest type and it has a vegetation of grasses and scattered tree. The study location is underlain by the Precambrian Basement Complex of Southwestern Nigeria [10], comprising of two major petrologic units which are Porphyritic Granite and Quartzite. Researches have shown that Granitic rocks are often characterized or associated with some geotechnical problems [11]. Furthermore, quartzite is highly vulnerable to fracturing and can 
therefore contain features that can facilitate foundation failure if not handle with utmost care during construction.

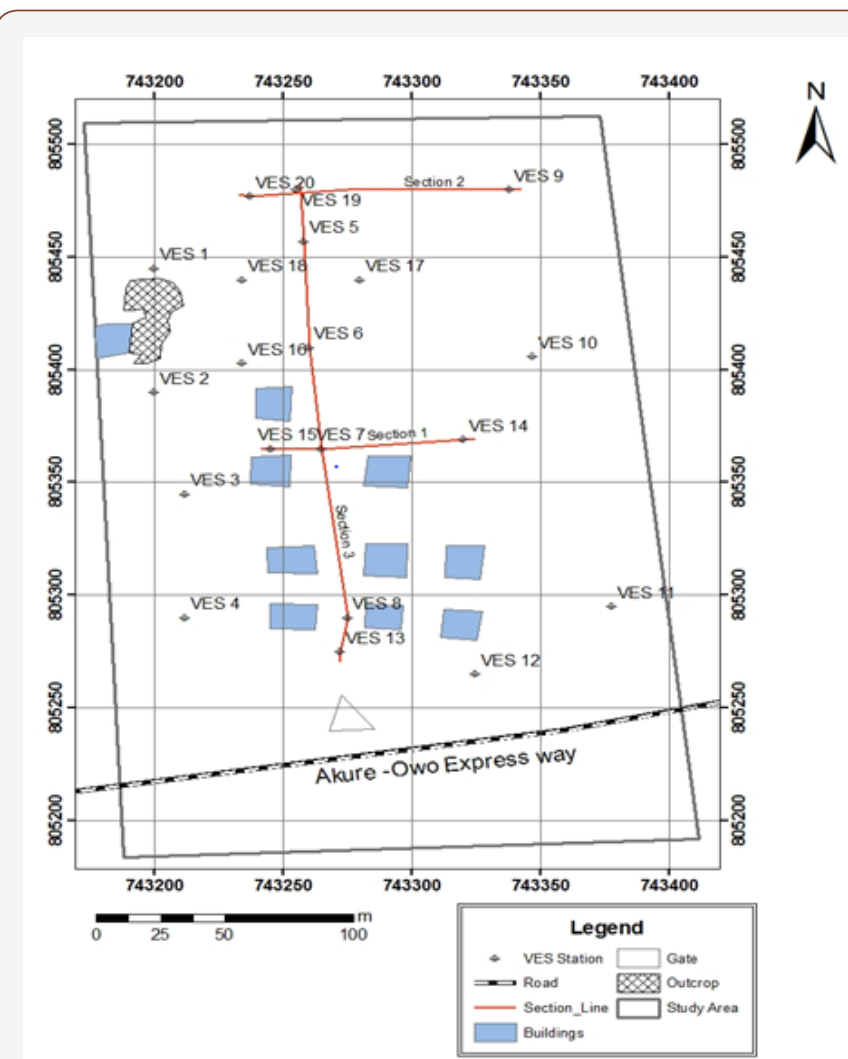

Figure 1: Base map of the Study Area showing VES Locations and other Features.

\section{Materials and Methodology}

The electrical resistivity data was acquired using the R-50 Resistivity meter and its accessories. The study utilized the Vertical Electrical Sounding (VES) technique using the Schlumberger electrode configuration. A total of twenty (20) VES stations were occupied. In order to guarantee proper subsurface representation, adequate spatial distribution of the VES stations was ensured (Figure 1). The survey was carried out by gradually expanding the electrode spacing about a fixed center of the array. The electrode spread of $A B / 2$ was varied from $1 \mathrm{~m}$ to a maximum $100 \mathrm{~m}$. The apparent resistivity of each electrode separation at each of the VES station being investigated was determined by multiplying the ground resistance $(\mathrm{R})$ value by the corresponding geometric factor (K). The VES data were presented as depth sounding curves by plotting the apparent resistivity in Ohm-meter $(\Omega \mathrm{m})$ on the vertical (Y axis) against the electrode spacing $(\mathrm{AB} / 2) \mathrm{m}$ on the horizontal $(\mathrm{X}$ axis) on a bi-log paper. The VES data were qualitatively interpreted by mere visual inspection with a view to appropriately classifying the field curves obtained for the location being interpreted. On the other hand, partial curve matching [12] was employed for the quantitative interpretation using master and auxiliary curves [1315] to obtain geoelectric parameters for delineated geoelectric layers at each VES location. These parameters were used for the computer iteration [16] to obtain improved subsurface geoelectric parameters in the area. In order to determine number of subsurface layers obtainable in the area and also to identify the presence/ absence of subsurface features that can undermine foundation integrity in the area, three geoelectric sections, trending in different directions, were prepared from the results of the interpretation of VES data. Similarly, layers resistivities and thicknesses maps were also produced. These were used to assess/evaluate the resistivity and thickness distribution of each of the subsurface layers and their implications on foundation integrity of engineering structures in the area. foundation integrity of engineering structures in the area.

\section{Results and Discussion}

The summary of the results of interpretation of the VES data is presented in Table 1 . Seven curve types $(\mathrm{H}, \mathrm{K}, \mathrm{KH}, \mathrm{KH}, \mathrm{QH}, \mathrm{KQ}$, $\mathrm{HA}$ and $\mathrm{HKH}$ ) were obtained from the area. The $\mathrm{H}, \mathrm{KH}$, and $\mathrm{HKH}$ curve types (respectively has 5, 8 and 2) account for $75 \%$ of the VES carried out in the area. This suggests that the area is largely characterized by the presence of highly weathered/fractured basement layers. The presence of these features can lead to foundation failure particularly if these layers are either saturated with water or contain clayish material and also if the foundation has to rest on the layers due to thinness of the layer overlying them.

Table 1: Results of interpretation of the VES data.

\begin{tabular}{|c|c|c|c|}
\hline $\begin{array}{l}\text { VES } \\
\text { No }\end{array}$ & $\begin{array}{c}\text { Layers Geoelectric } \\
\text { Parameters } \\
\text { (Resistivities } \\
\text { (Ohm-m)/Thickness } \\
\text { (m) }\end{array}$ & $\begin{array}{l}\text { Curve } \\
\text { Type }\end{array}$ & $\begin{array}{l}\text { Possible Lithologic } \\
\text { Equivalence }\end{array}$ \\
\hline \multirow{2}{*}{1} & \multirow{2}{*}{$\begin{array}{c}433 / 0.6 \\
483 / 8.7 / 248 / 12.5 \\
1460\end{array}$} & \multirow{2}{*}{$\mathrm{KH}$} & $\begin{array}{c}\text { Top Soil/ Lateritic } \\
\text { Hardpan/weathered } \\
\text { Basement / Basement }\end{array}$ \\
\hline & & & $\begin{array}{c}\text { Top Soil/Clayey Sand } \\
\text { weathered Basement / } \\
\text { Sandy Clay }\end{array}$ \\
\hline 2 & $\begin{array}{l}\text { 237/0.8; 198/8.4; } \\
\text { 71/15.4; } 3075\end{array}$ & $\mathrm{QH}$ & $\begin{array}{c}\text { Weathered Basement / } \\
\text { Basement }\end{array}$ \\
\hline 3 & $\begin{array}{c}569 / 1.7 ; 711 / 2.0 ; \\
150 / 3.7 ; 612\end{array}$ & $\mathrm{KH}$ & Same as VES 1 \\
\hline 4 & 795/1.6; 61/16.8; 1151 & $\mathrm{H}$ & $\begin{array}{l}\text { Top Soil / Weathered } \\
\text { Basement / Basement }\end{array}$ \\
\hline 5 & $\begin{array}{c}\text { 434/0.6; 483/8.6; } \\
\text { 250/12.6; } 1422\end{array}$ & $\mathrm{KH}$ & Same as VES 1 \\
\hline 6 & $\begin{array}{c}\text { 457/1.1; 749/6.1; } \\
\text { 140/35.9; } 1831\end{array}$ & $\mathrm{KH}$ & Same as VES 1 \\
\hline 7 & $534 / 1.2 ; 61 / 16.9 ; 1413$ & $\mathrm{H}$ & Same as VES 4 \\
\hline 8 & 179/1.0; 34/5.2; 1013 & $\mathrm{H}$ & Same as VES 4 \\
\hline 9 & $\begin{array}{c}\text { 843/1.3; 1336/6.3; } \\
\text { 390/11.1; } 2281\end{array}$ & $\mathrm{KH}$ & Same as VES 1 \\
\hline 10 & $\begin{array}{c}281 / 1.5 ; 470 / 0.8 \\
77 / 2.0 ; 549\end{array}$ & $\mathrm{KH}$ & Same as VES 1 \\
\hline 11 & $\begin{array}{c}511 / 0.7 ; 198 / 0.8 \\
629 / 10.1 ; 1141\end{array}$ & HA & $\begin{array}{c}\text { Top Soil/Clay/Partly } \\
\text { Weathered Basement / } \\
\text { Basement }\end{array}$ \\
\hline 12 & $\begin{array}{c}\text { 216/0.8; 497/3.3; } \\
167 / 24.4 ; 6937\end{array}$ & $\mathrm{KH}$ & Same as VES 1 \\
\hline 13 & $\begin{array}{c}\text { 280/0.6; 520/1.4; } \\
59 / 4.7 ; 297\end{array}$ & $\mathrm{KH}$ & Same as VES 1 \\
\hline \multirow[b]{2}{*}{14} & \multirow[b]{2}{*}{$347 / 0.7 ; 216 / 4.0 ; 9500$} & \multirow[b]{2}{*}{$\mathrm{H}$} & Same as VES 4 \\
\hline & & & $\begin{array}{l}\text { Top Soil /Sandy Clay/ } \\
\text { Clayey Sand/ Fractured }\end{array}$ \\
\hline
\end{tabular}




\begin{tabular}{|c|c|c|c|}
\hline 15 & $\begin{array}{c}\text { 291/2.3; 97/2.7; } \\
588 / 3.5 ; 63 / 7.9 ; 1181\end{array}$ & KHKH & Basement/Basement \\
\hline 16 & $\begin{array}{c}\text { 759/1.5; 36/16.2; } \\
\text { 5432; 765/0.6; } \\
247 / 1.6 ; 634 / 4.7\end{array}$ & $\mathrm{H}$ & Same as VES 4 \\
\hline \multirow[b]{2}{*}{17} & \multirow[b]{2}{*}{$285 / 28.7 ; 479$} & \multirow[b]{2}{*}{ HKH } & Same as VES 15 \\
\hline & & & $\begin{array}{c}\text { Top Soil/ Lateritic } \\
\text { Hardpan/weathered } \\
\text { Basement / Fractured }\end{array}$ \\
\hline 18 & $\begin{array}{c}688 / 0.9 ; 2411 / 3.1 \\
457 / 6.6 ; 66\end{array}$ & KQ & Basement \\
\hline 19 & $579 / 1.0 ; 720 / 6.0 ; 364$ & K & $\begin{array}{c}\text { Top Soil/ Lateritic } \\
\text { Hardpan/ Fractured } \\
\text { Basement }\end{array}$ \\
\hline 20 & $\begin{array}{c}560 / 0.8 ; 248 / 4.2 \\
650 / .8 ; 37\end{array}$ & HK & $\begin{array}{c}\text { Top Soil/Clay/Lateritic } \\
\text { Hardpan/ Fractured } \\
\text { Basement }\end{array}$ \\
\hline
\end{tabular}

The geoelectric sections prepared along the three section lines orienting in different directions as shown in Figure 1 are presented in Figures 2a-2c.

A maximum of four subsurface geoelectric layers (top soil, clayey layer, weathered/fractured basement and basement) were delineated. These layers can however be classified into three geologic models/layers which are the top soil, weathered/fractured basement and basement.

The top soil has varying resistivity and thickness values suggesting inhomogeneity nature of the materials constituting this layer. It is noted that the top soil has a very thin thickness, especially as observed in Figures 2a\&2b. The implication of this, among other things, is that the foundation may be inevitably footed on the layer underlain the top soil as most part of the top soil may have been removed during construction thereby making the integrity of the building to be solely dependent on the materials constituting the underlain layer(s) [17].

The second geologic layer has resistivity and thickness values respectively ranging between 34 and 749 ohm-m and $0.7-36 \mathrm{~m}$. A relatively large column of clayish materials is delineated beneath the top soil in some parts of the area (Figures 2a \& 2c). If the foundation should be footed on this layer, the differential settlement capability of clay might facilitate structural failure of such foundations. Similarly, vertical/near-vertical features suspected to be contacts between different geologic and or geoelectric materials (indicated in red arrows) are also delineated as shown in Figures 2a \& 2c while presence of fractures (indicated as red-letter F) were also observed in some parts of the area (Figures 2a). The presence of these features will further make buildings located around their vicinity to be vulnerable to structural failure if not properly handle during construction.

The basement is highly resistive with resistivity values of over $100 \mathrm{ohm}-\mathrm{m}$ in the area. The basement topography is generally observed to be undulating except for few places where it is relatively flat (Figure 2b). Furthermore, basement depressions (denoted by red-letter D) and ridge (denoted by red-letter $\mathrm{R}$ ) were observed in some parts of the area (Figures 2a \& 2c). Depressions and ridges can aggravate foundation failure particularly if it is at shallow depth as is the case shown in Figure 2a.
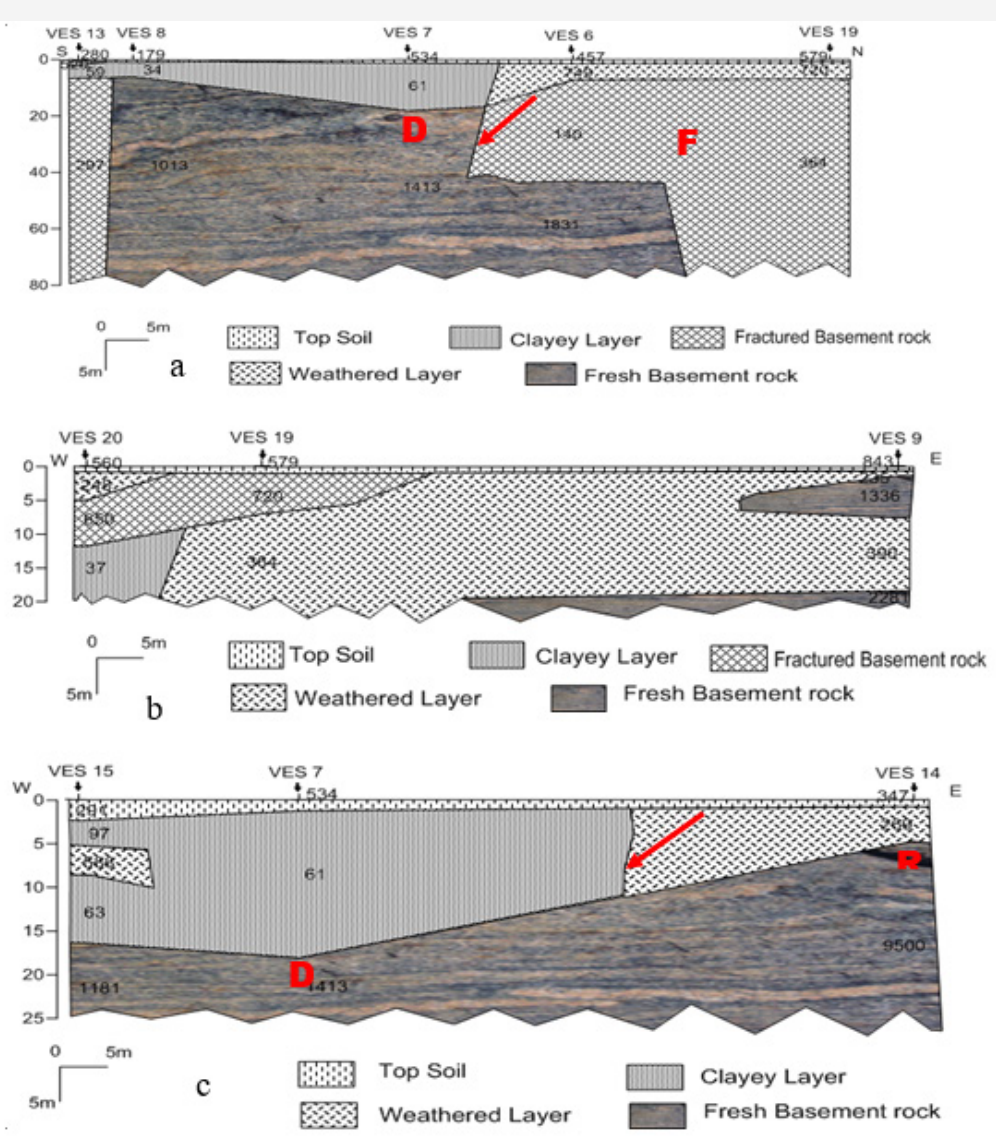

Figure 2(a,b,c): Geoelectric Sections from the Study Area. 


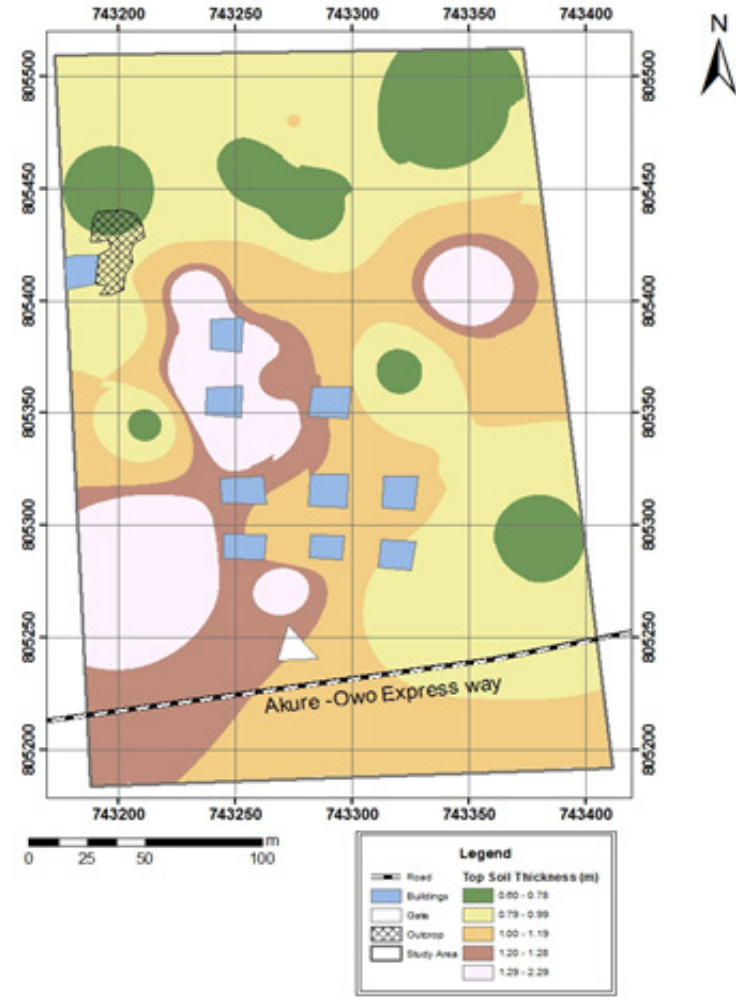

Figure 3: Top soil Thickness Map.

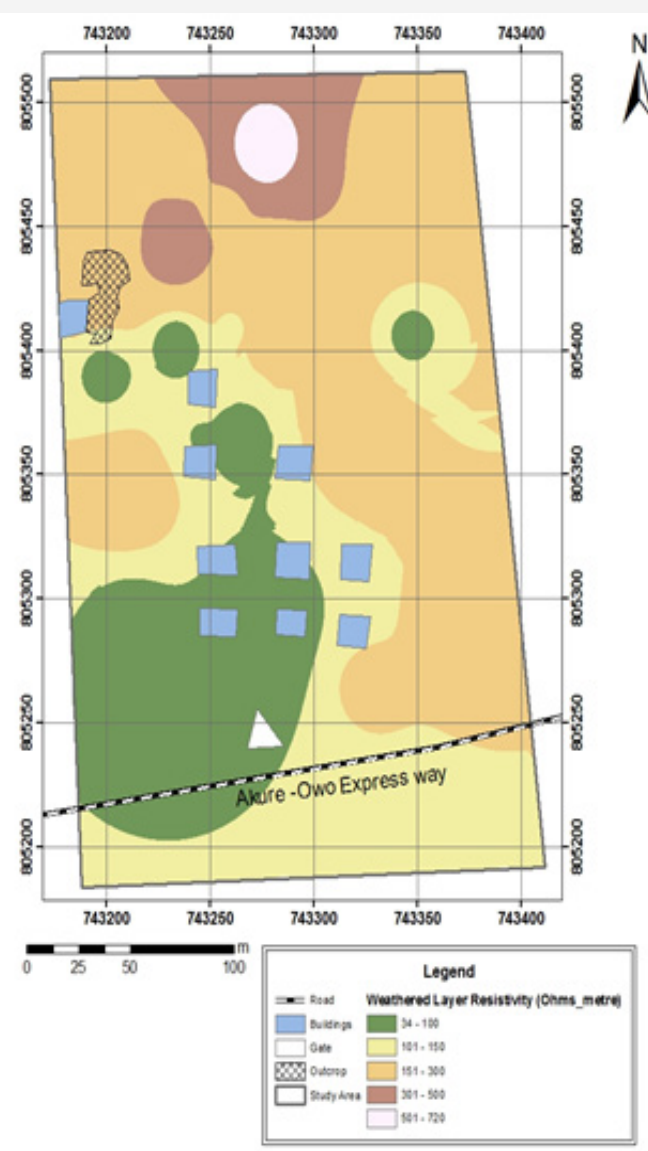

Figure 4: Top soil Thickness Map.

The subsurface spatial distribution of the thickness of top soil layer is shown in Figure 3. Top soil thickness varies between 0 and
$2.29 \mathrm{~m}$. It is however observed that the larger parts of the area where buildings are located are characterized by thickness of between $0-1.1 \mathrm{~m}$. This means that the footing of foundation may have to be extended to the weathered layer underlain the top soil owning to the thinness of the top layer [18]. The weathered layer resistivity distribution map is shown in Figure 4. The resistivity of this layer varies between 34 and $720 \mathrm{ohm}-\mathrm{m}$. Most of the existing structures are within resistivity classes of 34-100 ohm-m and 101-150 ohm-m. These resistivity classes are indicative of either presence of clayey materials of water saturation. This thus suggests that foundation in the area will be vulnerable to failure if not adequately handled during construction.

\section{Conclusion}

The focus of engineering geophysics is to provide quantitative information leading to adequate understanding of subsurface condition of soils and rocks. Such understandings are required for designing and construction of any civil engineering structures. Although building foundations failures can occur if foundations are not properly built, but it is also a fact that buildings located on anomalous subsurface zones that are inadequate for bearing the load of structure put on it are highly vulnerable to collapse.

The prediction and occurrence of these zones can be extremely difficult in basement terrain environment. This is because inhomogeneity of materials in these geologic terrains can abruptly truncate the continuity and or uniformity of such zones thus making their pattern of occurrence complex to predict. Several reported cases of building collapse in the country in the recent time have necessitated subsurface investigations using noninvasive geophysical methods to compliment or guide conventional geotechnical testing. The efficiency of electrical resistivity geophysical method to detect such anomalous zones in a difficult geologic terrain had been demonstrated in this study. Twenty (20) VES were acquired using R-50 Resistivity meter and the results obtained were both qualitatively and quantitatively interpreted. The dominant curve types obtained suggest that the study area is largely characterized by the presence of highly weathered/fractured basement with evident of saturation. Three geologic layers were generally delineated, and these were top soil, weathered/fractured basement and the basement. The top soil was observed to be of thin thickness indicating that the foot of the foundation might inevitably be extended to the layer underlain the top soil. Series of anomalous zones such as fractures, contacts, basement depressions and ridges capable of causing foundation failure were delineated in the layers underlain the top soil in some parts of the area. The study has demonstrated that electrical resistivity as a geophysical tool be used in understanding the subsurface such that it can complement conventional geotechnical studies in engineering site characterization

\section{Acknowledgement}

The author expresses his profound gratitude to Ologundudu, Bunmi and Ademusere, Oluwasegun Ebenezer for their assistance during data acquisition and data processing phases of this work. Mr. Musa Bawallah, a chief Technologist in the department, is highly appreciated for his roles during data acquisition. 


\section{Conflict of Interest}

No conflict of interest.

\section{References}

1. Coduto DP, Man Chu Ronald Yeung, William A Kitch (1999) Geotechnical Engineering: Principles and Practices. Upper Saddle River: PrenticeHall, India, 1-773.

2. Hubbard JL (2009) Use of electrical resistivity and multichannel analysis of surface wave geophysical tomography in geotechnical site characterization of dam (M.Sc Thesis, Unpublished). The University of Texas, Arlington, 1-124.

3. Steeples Don (2001) Engineering and Environmental Geophysics at the Millenium. Geophysics, 66(1): 31-35.

4. Anderson NL, Ismail AM, Thitimakorn T (2007) Ground-Penetrating Radar: A Tool for Monitoring Bridge Scour. Environmental and Engineering Geoscience 13(1): 1-10.

5. Sirles PC (2006) Use of Geophysics for Transportation Projects, Transportation Research Board of the National Academies, Washington, DC, (NCHRP Synthesis 357).

6. Soupios PM, Papazachos CB, Vargemezis G, Fikos I (2005) Application of modern seismic methods for geotechnical site characterization Proc. Int Workshop in Geoenvironment and Geotechnics (Milos Island, Greece, 12-14 September), pp 163-70.

7. Soupios PM, Papazachos CB, Vargemezis G, Savvaidis A (2006) In situ geophysical investigation to evaluate dynamic soil properties at the Ilarionas Dam, Northern Greece Proc. 2nd Int. Conf. Advances in Mineral Resources Management and Environmental Geotechnology (Hania, Crete, Greece, 25-27 September 2006) (Heliotopos Conferences), pp. $149-56$.
8. Venkateswara VR, Srinivasa R, Prakasa RBS, Koteswara RP (2004) Bedrock investigation by seismic refraction method-a case study J Ind Geophys Union 8(3): 223-8.

9. Soupios PM, Georgakopoulos P, Papadopoulos N, Saltas V, Andreadakis A, et al. (2007) Use of engineering geophysics to investigate a site for a building foundation. J Geophys Eng 4: 94-103.

10. Owoyemi JM (1997) Metal, The Age Long Material for Industrial Products. Paper Presented at The Maiden Conference On Industrial Design And Technology, FUTA, Akure, $8^{\text {th }}-11^{\text {th }}$ April 1997. Book Of Abstracts, pp 29.

11. Adiat KAN, Akinlalu AA, Adegoroye AA (2017) Evaluation of road failure vulnerability section through integrated geophysical and geotechnical studies. NRIAG Journal of Astronomy and Geophysics 6(1): 244-255.

12. Koefoed O (1979) Geosounding Principles, 1. Resistivity Sounding Measurements. Elsevier Scientific Publishing Comp., Amsterdam, The Netherlands, pp. 275.

13. Orellana E, Mooney HM (1966) Master tables and curves for vertical electrical sounding over layered structures. Inteciencis, Madrib, pp. 34.

14.Zohdy AAR (1965) The auxiliary point method of electrical sounding interpretation and its relationship to dar Zorrouk parameters. Geophysics 30(4): 644-650.

15. Keller GV, Frischknecht FC (1966) Electrical methods in geophysical prospecting. Pergamon Press Inc., Oxford.

16. Vander Velpen BPA (1989) RESIST Version 1.0. M.Sc. Research Project. ITC, Delft Netherlands.

17. Anderson NL, Croxton N, Hoover R, Sirles PC (2008) Geophysical methods commonly employed for geotechnical site characterization. Transportation Research Circular E-C130, pp. 1-35.

18. Day RW (2006) Foundation Engineering Handbook: Design and Construction with the 2006. Internation Building Code. New York, USA. 